\title{
Pedobacter lentus sp. nov. and Pedobacter terricola sp. nov., isolated from soil
}

\author{
Jung-Hoon Yoon, So-Jung Kang, Sooyeon Park and Tae-Kwang Oh \\ Korea Research Institute of Bioscience and Biotechnology (KRIBB), PO Box 115, Yusong, Taejon, \\ Korea
}

Correspondence

Jung-Hoon Yoon

jhyoon@kribb.re.kr
Two Gram-negative, non-motile, pleomorphic bacterial strains, DS $-40^{\top}$ and $D S-45^{\top}$, were isolated from a soil sample collected from Dokdo, Korea, and their exact taxonomic positions were investigated by using a polyphasic approach. Strains DS- $40^{\top}$ and DS $-45^{\top}$ grew optimally at $25{ }^{\circ} \mathrm{C}$ and $\mathrm{pH} 6.5-7.5$ in the presence of $0-1.0 \%(\mathrm{w} / \mathrm{v}) \mathrm{NaCl}$. They contained MK-7 as the predominant menaquinone and possessed iso- $\mathrm{C}_{15: 0}$, iso- $\mathrm{C}_{17: 0} 3-\mathrm{OH}$ and summed feature 3 $\left(\mathrm{C}_{16: 1} \omega 7 \mathrm{c}\right.$ and/or iso- $\left.\mathrm{C}_{15: 0} 2-\mathrm{OH}\right)$ as the major fatty acids. The DNA G+C contents of strains DS $-40^{\top}$ and DS $-45^{\top}$ were 36.0 and 36.8 mol\%, respectively. Strains DS $-40^{\top}$ and DS $-45^{\top}$ shared a $16 \mathrm{~S}$ rRNA gene sequence similarity of $96.7 \%$ and demonstrated a mean DNA-DNA relatedness level of $12 \%$. Phylogenetic analyses based on $16 \mathrm{~S}$ rRNA gene sequences revealed that strains DS $-40^{\top}$ and $D S-45^{\top}$ were most closely phylogenetically affiliated with the genus Pedobacter of the family Sphingobacteriaceae. Strains DS $-40^{\top}$ and DS $-45^{\top}$ exhibited $16 \mathrm{~S}$ rRNA gene sequence similarity values of $91.4-93.7$ and $89.9-91.6 \%$ with respect to the type strains of Pedobacter and Sphingobacterium species, respectively. Phenotypic and chemotaxonomic properties, together with the phylogenetic data, support the assignment of strains $D S-40^{\top}$ and DS $-45^{\top}$ as two distinct species within the genus Pedobacter. On the basis of phenotypic, phylogenetic and genetic data, strains $D S-40^{\top}$ and $D S-45^{\top}$ represent two novel species of the genus Pedobacter, for which the names Pedobacter lentus sp. nov. and Pedobacter terricola sp. nov. are proposed, respectively. The respective type strains are DS $-40^{\top}(=$ KCTC $\left.12875^{\top}=\mathrm{JCM} 14593^{\top}\right)$ and DS $-45^{\top}\left(=\right.$ KCTC $\left.12876^{\top}=J C M 14594^{\top}\right)$.
The genus Pedobacter was proposed by Steyn et al. (1998) through the reclassification of two Sphingobacterium species and the description of two novel species. Since then, the number of Pedobacter species has increased considerably with the description of many novel members of the genus. Interestingly, most of these recently described novel Pedobacter species have been isolated from a variety of soils from Korea (Yoon et al., 2006, 2007; Hwang et al., 2006; Ten et al., 2006; Kwon et al., 2007). In this study, we describe two bacterial strains, DS $-40^{\mathrm{T}}$ and DS $-45^{\mathrm{T}}$, which were isolated from soil from the island of Dokdo, Korea. Comparative 16S rRNA gene sequence analyses indicated that the two strains are phylogenetically affiliated with the family Sphingobacteriaceae, which includes the genera Pedobacter and Sphingobacterium (Steyn et al., 1998; Bernardet et al., 2002). Accordingly, the aim of the present work was to determine the exact taxonomic positions of strains $\mathrm{DS}-40^{\mathrm{T}}$ and $\mathrm{DS}-45^{\mathrm{T}}$ by using a polyphasic

The GenBank/EMBL/DDBJ accession numbers for the 16S rRNA gene sequences of strains DS- $40^{\top}$ and $D S-45^{\top}$ are EF446146 and EF446147, respectively.

The cellular fatty acid compositions of strains DS- $40^{\top}$ and DS $-45^{\top}$ are available in a supplementary table with the online version of this paper. characterization that included phenotypic and chemotaxonomic analyses, a detailed phylogenetic investigation based on 16S rRNA gene sequences and determination of the levels of genetic relatedness.

A soil sample collected from the island of Dokdo $\left(37^{\circ} 14^{\prime}\right.$ $12^{\prime \prime} \mathrm{N} 131^{\circ} 52^{\prime} 07^{\prime \prime} \mathrm{E}$ ), Korea, was used as the source for the isolation of bacterial strains. Strains DS $-40^{\mathrm{T}}$ and DS $-45^{\mathrm{T}}$ were isolated by means of the standard dilution plating technique, at $25{ }^{\circ} \mathrm{C}$ on $10 \times$ diluted nutrient agar (NA; Difco). The morphological, physiological and biochemical characteristics of strains DS $-40^{\mathrm{T}}$ and DS $-45^{\mathrm{T}}$ were investigated using routine cultivation on NA at $25^{\circ} \mathrm{C}$. Cell morphology was examined by using light microscopy (E600; Nikon) and transmission electron microscopy. Flagellation was determined by using a Philips CM-20 transmission electron microscope with cells from exponentially growing cultures: for this purpose, the cells were negatively stained with $1 \%(\mathrm{w} / \mathrm{v})$ phosphotungstic acid and the grids were examined after being air-dried. Gliding motility was determined as described by Bowman (2000), using quarterstrength nutrient broth (NB; Difco) solidified with $1 \%$ (w/v) agarose and R2A agar (Difco). The Gram reaction was determined by using the bioMérieux Gram stain kit 
Table 1. Differential phenotypic characteristics of strains DS- $40^{\top}$ and DS- $45^{\top}$ and Pedobacter species

Taxa: 1, strain DS-40 ${ }^{\mathrm{T}}$ (Pedobacter lentus sp. nov.); 2, strain DS-45 ${ }^{\mathrm{T}}$ (Pedobacter terricola sp. nov.); 3, Pedobacter heparinus; 4, Pedobacter africanus; 5, Pedobacter piscium; 6, Pedobacter cryoconitis; 7, Pedobacter himalayensis; 8, Pedobacter caeni; 9, Pedobacter ginsengisoli; 10, Pedobacter panaciterrae; 11, Pedobacter sandarakinus; 12, Pedobacter roseus; 13, Pedobacter aquatilis. Data are from Steyn et al. (1998), Margesin et al. (2003), Shivaji et al. (2005), Vanparys et al. (2005), Gallego et al. (2006), Hwang et al. (2006), Ten et al. (2006), Yoon et al. (2006, 2007) and this study. All are positive for catalase, oxidase, acid phosphatase (data for P. cryoconitis, P. himalayensis, P. ginsengisoli and P. panaciterrae from this study), alkaline phosphatase (data for P. cryoconitis, P. himalayensis, P. ginsengisoli and P. panaciterrae from this study), esterase lipase (C8) (data for P. cryoconitis, P. himalayensis, P. ginsengisoli and P. panaciterrae from this study), leucine arylamidase (data for P. cryoconitis, $P$. himalayensis, $P$. ginsengisoli and $P$. panaciterrae from this study) and assimilation of D-glucose, D-mannose, $N$-acetylglucosamine, lactose and trehalose. All are negative for Gram-stain, sporulation, urease, production of $\mathrm{H}_{2} \mathrm{~S}$ (not determined for P. roseus) and indole, nitrate reduction and for assimilation of erythritol (data for P. ginsengisoli and P. panaciterrae from this study), L-sorbose, dulcitol, D-lyxose (data for $P$. himalayensis from this study), D-tagatose (data for P. himalayensis, $P$. ginsengisoli and $P$. panaciterrae from this study), D-fucose (data for P. himalayensis from this study), L-arabitol (data for $P$. himalayensis, $P$. ginsengisoli and $P$. panaciterrae from this study), gluconate (data for $P$. himalayensis from this study), adipate (data for $P$. himalayensis from this study), caprate (data for $P$. himalayensis from this study), phenylacetate (data for $P$. himalayensis from this study), citrate and malate. + , Positive reaction; - , negative reaction; w, weakly positive reaction; v, variable reaction; ND, not determined. Data in parentheses are for the type strain.

\begin{tabular}{|c|c|c|c|c|c|c|c|c|c|c|c|c|c|}
\hline Characteristic & 1 & 2 & 3 & 4 & 5 & 6 & 7 & 8 & 9 & 10 & 11 & 12 & 13 \\
\hline Cell shape & Pleomorphic & Pleomorphic & Short rods & $\mathrm{ND}$ & Long rods & Long rods & Long rods & Rods & Rods & Rods & $\begin{array}{l}\text { Rods/long } \\
\text { rods }\end{array}$ & $\begin{array}{l}\text { Short } \\
\text { rods }\end{array}$ & Rods \\
\hline Colony colour & $\begin{array}{l}\text { Pale yellow to } \\
\text { pale orange }\end{array}$ & Pale orange & $\begin{array}{c}\text { Translucent } \\
\text { yellow }\end{array}$ & $\begin{array}{l}\text { Translucent } \\
\text { yellow }\end{array}$ & $\begin{array}{c}\text { Yellow or } \\
\text { creamy } \\
\text { white }\end{array}$ & $\begin{array}{l}\text { Creamy } \\
\text { white }\end{array}$ & Pale white & $\begin{array}{l}\text { Creamy } \\
\text { white to } \\
\text { yellow }\end{array}$ & White & White & Orange & Pink & Pink \\
\hline $\begin{array}{l}\text { Maximum growth } \\
\text { temperature }\left({ }^{\circ} \mathrm{C}\right)\end{array}$ & 31 & 34 & 37 & 37 & $25-30$ & 25 & 25 & 37 & 30 & 30 & 33 & 33 & 30 \\
\hline $\begin{array}{l}\text { Growth on MacConkey } \\
\text { medium }\end{array}$ & - & - & - & - & - & - & + & ND & - & - & - & + & - \\
\hline Motility & - & - & Gliding & - & - & Gliding & - & - & - & - & - & - & - \\
\hline Arginine dihydrolase & - & - & - & - & - & - & + & - & - & - & - & - & - \\
\hline Lysine decarboxylase & - & - & + & + & + & - & - & $\mathrm{ND}$ & - & - & - & $\mathrm{ND}$ & $\mathrm{ND}$ \\
\hline Tryptophan deaminase & - & - & - & - & - & - & + & $\mathrm{ND}$ & - & - & - & $\mathrm{ND}$ & ND \\
\hline Hydrolysis of aesculin & + & + & + & + & + & + & + & + & - & - & + & + & + \\
\hline \multicolumn{14}{|l|}{$\begin{array}{l}\text { Enzyme activities (API } \\
\text { ZYM) }\end{array}$} \\
\hline Esterase (C4) & + & + & $+^{*}$ & - & $+^{*}$ & $\mathrm{w}^{\dagger}$ & $\mathrm{w}^{\dagger}$ & - & $+\dagger$ & $-\dagger$ & + & + & + \\
\hline Lipase (C14) & - & - & $-*$ & - & $\mathrm{V}^{*}$ & $-\dagger$ & $-\dagger$ & - & $-\dagger$ & $-\dagger$ & - & - & - \\
\hline Valine arylamidase & + & + & $-{ }^{\star}$ & $\mathrm{v}(-)$ & $+^{*}$ & $+\dagger$ & $-\dagger$ & - & $+\dagger$ & $+\dagger$ & - & + & + \\
\hline Cystine arylamidase & + & + & $+^{*}$ & - & $+^{*}$ & $-\dagger$ & $-\dagger$ & - & $+\dagger$ & $-\dagger$ & $\mathrm{w}$ & - & + \\
\hline Trypsin & - & - & $-*$ & - & $+^{*}$ & $-\dagger$ & $-\dagger$ & - & $-\dagger$ & $-\dagger$ & - & + & + \\
\hline$\alpha$-Chymotrypsin & + & + & $+^{*}$ & - & $+^{*}$ & $-\dagger$ & $-\dagger$ & - & $-\dagger$ & $-\dagger$ & - & + & - \\
\hline $\begin{array}{l}\text { Naphthol-AS-BI- } \\
\text { phosphohydrolase }\end{array}$ & + & + & + & + & $\mathrm{ND}$ & $+\dagger$ & $+\dagger$ & - & $+\dagger$ & $+\dagger$ & + & + & + \\
\hline$\alpha$-Galactosidase & - & - & $+^{*}$ & - & $+^{\star}$ & $-\dagger$ & $-\dagger$ & - & $+\dagger$ & $+\dagger$ & - & + & - \\
\hline$\beta$-Galactosidase & + & + & + & + & + & $-\dagger$ & $-\dagger$ & + & - & + & + & - & + \\
\hline$\beta$-Glucuronidase & - & - & $-{ }^{*}$ & - & $\mathrm{V}^{*}$ & $-\dagger$ & $-\dagger$ & - & $-\dagger$ & $-\dagger$ & - & - & - \\
\hline$\alpha$-Glucosidase & + & + & + & + & + & $+\dagger$ & $w_{\dagger}^{\dagger}$ & - & $+\dagger$ & $+\dagger$ & + & + & + \\
\hline
\end{tabular}




\begin{tabular}{|c|c|c|c|c|c|c|c|c|c|c|c|c|c|}
\hline Characteristic & 1 & 2 & 3 & 4 & 5 & 6 & 7 & 8 & 9 & 10 & 11 & 12 & 13 \\
\hline$\beta$-Glucosidase & - & - & $+^{*}$ & $\mathrm{v}(-)$ & $+^{*}$ & + & + & - & $-\dagger$ & $-\dagger$ & + & - & + \\
\hline $\begin{array}{l}N \text {-Acetyl- } \beta \text {-glucos- } \\
\text { aminidase }\end{array}$ & + & + & + & + & + & $+\dagger$ & $+\dagger$ & - & $+\dagger$ & $+\dagger$ & + & + & + \\
\hline$\alpha$-Mannosidase & - & - & $+^{*}$ & $\mathrm{v}(\mathrm{w})$ & $+^{*}$ & $-\dagger$ & $-\dagger$ & - & $-\dagger$ & $-\dagger$ & - & - & + \\
\hline$\alpha$-Fucosidase & - & - & $-^{*}$ & - & $-^{*}$ & $-\dagger$ & $\mathrm{w}^{\dagger}$ & - & $-\dagger$ & $\mathrm{w} \dagger$ & - & - & - \\
\hline \multicolumn{14}{|l|}{ Assimilation of: } \\
\hline Glycerol & - & - & - & - & - & - & + & - & + & + & - & + & - \\
\hline D-Arabinose & - & - & - & $\mathrm{v}(-)$ & - & - & + & - & - & + & - & - & - \\
\hline L-Arabinose & + & + & + & $\mathrm{v}(+)$ & + & + & + & + & - & + & - & + & + \\
\hline Ribose & - & - & - & $\mathrm{v}(-)$ & - & - & + & - & - & - & - & - & - \\
\hline D-Xylose & + & + & + & $\mathrm{v}(+)$ & + & + & + & - & + & + & - & $\mathrm{ND}$ & - \\
\hline L-Xylose & - & - & - & - & - & - & + & + & + & + & - & + & - \\
\hline Adonitol & - & - & + & - & - & - & + & - & - & - & - & - & - \\
\hline Methyl $\beta$-D-xyloside & - & - & - & - & - & - & - & - & $-\dagger$ & $+\dagger$ & - & $\mathrm{ND}$ & - \\
\hline D-Galactose & - & - & + & + & $\mathrm{v}$ & + & + & - & + & - & + & + & + \\
\hline D-Fructose & - & - & + & $\mathrm{v}(-)$ & + & + & + & - & + & - & - & + & + \\
\hline L-Rhamnose & + & + & + & + & $\mathrm{v}$ & - & + & - & - & - & - & + & + \\
\hline Inositol & - & - & - & - & - & - & - & - & - & + & - & - & - \\
\hline Mannitol & - & - & + & - & - & - & + & - & - & - & - & - & - \\
\hline D-Sorbitol & - & - & + & - & - & - & + & - & - & - & - & - & - \\
\hline Methyl $\alpha$-D-mannoside & - & - & + & + & - & - & + & + & $+\dagger$ & $+\dagger$ & $\mathrm{w}$ & $\mathrm{ND}$ & + \\
\hline Methyl $\alpha$-D-glucoside & - & - & + & + & + & w & + & + & $+\dagger$ & $+\dagger$ & $\mathrm{w}$ & $\mathrm{ND}$ & + \\
\hline Amygdalin & - & + & + & + & + & + & $+\dagger$ & + & + & + & + & + & + \\
\hline Arbutin & - & $\mathrm{w}$ & $\mathrm{v}(-)$ & $\mathrm{v}(-)$ & + & + & + & + & $-\dagger$ & $+\dagger$ & - & $\mathrm{ND}$ & + \\
\hline Salicin & - & - & + & $\mathrm{v}(+)$ & + & + & + & + & + & + & + & + & + \\
\hline Cellobiose & - & + & + & + & + & + & + & + & + & + & + & + & + \\
\hline Maltose & + & + & + & $\mathrm{v}(+)$ & + & + & + & + & + & + & + & + & + \\
\hline Melibiose & - & - & + & + & + & + & + & + & + & + & + & + & + \\
\hline Sucrose & - & - & + & + & + & + & + & + & + & + & + & + & + \\
\hline Inulin & - & - & - & - & - & w & + & - & + & + & - & + & - \\
\hline Melezitose & - & - & - & - & - & - & - & - & $+\dagger$ & $+\dagger$ & - & $\mathrm{ND}$ & + \\
\hline D-Raffinose & - & - & - & - & + & + & + & + & + & + & - & + & + \\
\hline Starch & + & + & - & $\mathrm{v}(-)$ & + & + & + & + & - & - & + & + & + \\
\hline Glycogen & $\mathrm{w}$ & + & - & - & - & + & - & - & - & - & + & + & - \\
\hline Xylitol & - & - & - & - & - & - & - & + & - & - & - & - & - \\
\hline Gentiobiose & $\mathrm{w}$ & + & + & $\mathrm{v}(+)$ & + & + & $+\dagger$ & + & $\mathrm{w} \dagger$ & $+\dagger$ & + & + & + \\
\hline D-Turanose & - & - & + & + & + & + & $+\dagger$ & - & $+\dagger$ & $+\dagger$ & - & $\mathrm{ND}$ & + \\
\hline L-Fucose & - & - & + & $\mathrm{v}(-)$ & - & - & + & - & $-\dagger$ & $-\dagger$ & - & - & - \\
\hline D-Arabitol & - & - & - & - & - & - & $-\dagger$ & - & $-\dagger$ & $+\dagger$ & - & - & - \\
\hline 2-Ketogluconate & - & - & - & - & - & + & $-\dagger$ & - & $-\dagger$ & $-\dagger$ & - & - & - \\
\hline 5-Ketogluconate & - & - & - & - & - & - & $-\dagger$ & - & $-\dagger$ & $-\dagger$ & + & $\mathrm{ND}$ & - \\
\hline
\end{tabular}




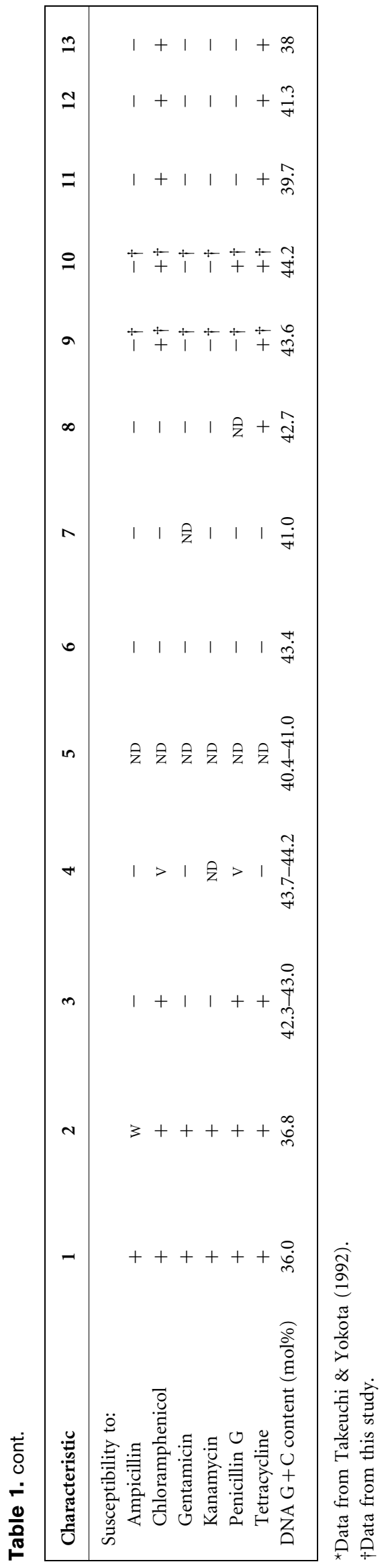

according to the manufacturer's instructions. Growth at various temperatures $\left(4-40{ }^{\circ} \mathrm{C}\right)$ was measured on NA. Growth in the absence of $\mathrm{NaCl}$ and at various $\mathrm{NaCl}$ concentrations $(0.5$ and $1.0-8.0 \%$, w/v, using increments of $1.0 \%$ ) was investigated in trypticase soy broth prepared according to the formula of the Difco medium, except that $\mathrm{NaCl}$ was excluded. The $\mathrm{pH}$ range for growth was determined in NB adjusted to various $\mathrm{pH}$ values ( $\mathrm{pH} 4.5-$ 10.5 , using increments of $0.5 \mathrm{pH}$ units), prior to sterilization, by the addition of $\mathrm{HCl}$ or $\mathrm{Na}_{2} \mathrm{CO}_{3}$. Growth under anaerobic conditions was determined after incubation in an anaerobic chamber on NA and on NA supplemented with nitrate, both of which had been prepared anaerobically using nitrogen. Catalase and oxidase activities and hydrolysis of casein, gelatin, hypoxanthine, starch, Tweens 20, 40, 60 and 80, tyrosine, urea and xanthine were determined as described by Cowan \& Steel (1965). Aesculin hydrolysis and nitrate reduction were studied as described by Lanyi (1987). The presence of flexirubin-type pigments was investigated as described by Reichenbach (1992). Susceptibility to antibiotics was tested on NA plates using antibiotic discs containing the following: polymyxin B, $100 \mathrm{U}$; streptomycin, $50 \mu \mathrm{g}$; penicillin $\mathrm{G}, 20 \mathrm{U}$; chloramphenicol, $100 \mu \mathrm{g}$; ampicillin, $10 \mu \mathrm{g}$; cephalothin, $30 \mu \mathrm{g}$; gentamicin, $30 \mu \mathrm{g}$; novobiocin, $5 \mu \mathrm{g}$; tetracycline, $30 \mu \mathrm{g}$; kanamycin, $30 \mu \mathrm{g}$; lincomycin, $15 \mu \mathrm{g}$; oleandomycin, $15 \mu \mathrm{g}$; neomycin, $30 \mu \mathrm{g}$; and carbenicillin, $100 \mu \mathrm{g}$. Assimilation of various substrates, enzyme activities and other physiological and biochemical properties were tested by using the API 20E, API 20NE, API $50 \mathrm{CH}$ and API ZYM systems (bioMérieux); assimilation of various substrates was determined by inoculating the API $50 \mathrm{CH}$ strip with cells suspended in AUX medium (bioMérieux).

Cell biomass for DNA extraction and for isoprenoid quinone analysis was obtained from cultivation in NB at $25{ }^{\circ} \mathrm{C}$. Chromosomal DNA was isolated and purified according to the method described by Yoon et al. (1996), with the exception that RNase T1 was used in combination with RNase A to minimize contamination with RNA. The $16 \mathrm{~S}$ rRNA gene was amplified by using PCR with two universal primers, as described previously (Yoon et al., 1998). Sequencing of the amplified $16 \mathrm{~S}$ rRNA gene and phylogenetic analysis were performed as described by Yoon et al. (2003). Isoprenoid quinones were extracted according to the method of Komagata \& Suzuki (1987) and analysed using reversed-phase HPLC and a YMC ODS-A $(250 \times$ $4.6 \mathrm{~mm}$ ) column. For fatty acid methyl ester analysis, cell mass of strains DS $-40^{\mathrm{T}}$ and DS- $45^{\mathrm{T}}$ was harvested from NA plates after incubation for 7 days at $25{ }^{\circ} \mathrm{C}$. The fatty acids were extracted and fatty acid methyl esters were prepared according to the standard protocol of the MIDI/Hewlett Packard Microbial Identification System (Sasser, 1990). The DNA $\mathrm{G}+\mathrm{C}$ content was determined by using the method of Tamaoka \& Komagata (1984), with the modification that DNA was hydrolysed and the resultant nucleotides were analysed by reversed-phase HPLC. DNADNA hybridization was performed fluorometrically by 


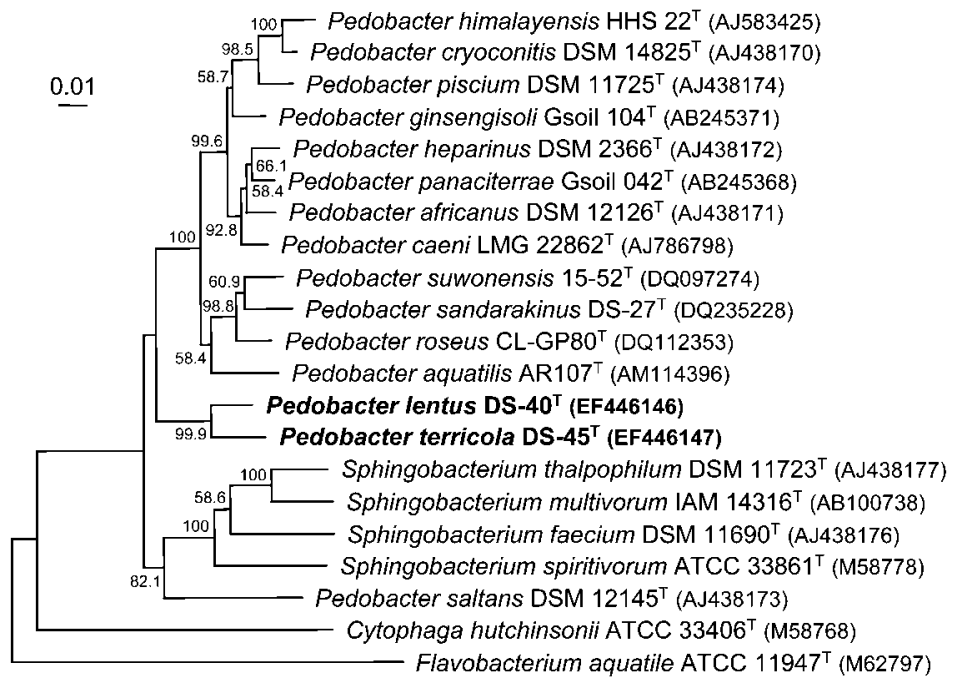

Fig. 1. Neighbour-joining phylogenetic tree, based on 16S rRNA gene sequences, showing the positions of strains $\mathrm{DS}-40^{\top}$ and DS $-45^{\top}$ and some related taxa. Bootstrap percentages (based on 1000 replications) $>50 \%$ are shown at nodes. Flavobacterium aquatile ATCC $11947^{\top}$ (GenBank accession number M62797) was used as an outgroup. Bar, 0.01 substitutions per nucleotide position. using the method of Ezaki et al. (1989) with photobiotinlabelled DNA probes and microdilution wells. Hybridization was performed with five replications for each sample. The highest and lowest values obtained for each sample were excluded and the means of the remaining three values were quoted as the DNA-DNA relatedness values.

Morphological, cultural, physiological and biochemical characteristics of strains DS- $40^{\mathrm{T}}$ and DS- $45^{\mathrm{T}}$ are given in the species description (see below) or are shown in Table 1 . The almost-complete $16 \mathrm{~S}$ rRNA gene sequences of strains DS- $-40^{\mathrm{T}}$ and DS- $45^{\mathrm{T}}$ determined in this study comprised 1477 and $1474 \mathrm{nt}$, respectively, representing approximately $96 \%$ of the Escherichia coli $16 \mathrm{~S}$ rRNA gene sequence. The $16 \mathrm{~S}$ rRNA gene sequence similarity between strains DS- $40^{\mathrm{T}}$ and DS- $45^{\mathrm{T}}$ was $96.7 \%$. Comparative $16 \mathrm{~S}$ rRNA gene sequence analyses showed that strains DS- $40^{\mathrm{T}}$ and DS- $45^{\mathrm{T}}$ were most closely related phylogenetically to the family Sphingobacteriaceae (Fig. 1). In the neighbour-joining tree constructed using 16S rRNA gene sequences, strains DS- $40^{\mathrm{T}}$ and DS- $45^{\mathrm{T}}$ formed a coherent cluster at a bootstrap resampling value of $99.9 \%$, and this cluster joined the clade comprising Pedobacter species (Fig. 1). Strains DS- $40^{\mathrm{T}}$ and DS- $45^{\mathrm{T}}$ exhibited 16S rRNA gene sequence similarity values of $91.4-93.7 \%$ with respect to the type strains of recognized Pedobacter species and showed values of $89.9-91.6 \%$ with respect to the type strains of recognized Sphingobacterium species. When the DNAs of strains DS $-40^{\mathrm{T}}$ and DS $-45^{\mathrm{T}}$ were used individually as labelled DNA probes for cross-hybridization, the mean level of DNADNA relatedness was $12 \%$, indicating that the two strains represent different genomic species (Wayne et al., 1987).

Strains DS $-40^{\mathrm{T}}$ and DS- $45^{\mathrm{T}}$ contained MK-7 (at peak area ratios of approximately $87-94 \%$ ) as the predominant isoprenoid quinone. The fatty acid profiles of strains DS $-40^{\mathrm{T}}$ and DS- $-45^{\mathrm{T}}$ showed the presence of large amounts of branched and hydroxy fatty acids; the major components were iso- $\mathrm{C}_{15: 0}$, iso- $\mathrm{C}_{17: 0} 3-\mathrm{OH}$ and summed feature
$3\left(\mathrm{C}_{16: 1} \omega 7 c\right.$ and/or iso- $\left.\mathrm{C}_{15: 0} 2-\mathrm{OH}\right)$ (see Supplementary Table S1, available in IJSEM Online). These fatty acid profiles were similar to those of other Pedobacter species, although there were differences in the proportions of some fatty acids, perhaps because of differences in the analytical conditions used (e.g. cultivation, extraction and apparatus) in the analyses (Shivaji et al., 2005; Vanparys et al., 2005; Yoon et al., 2006, 2007; Hwang et al., 2006; Ten et al., 2006). The DNA G+C contents of strains DS $-40^{\mathrm{T}}$ and DS- $45^{\mathrm{T}}$ were 36.0 and $36.8 \mathrm{~mol} \%$, respectively. There were no distinct phenotypic, and, in particular, chemotaxonomic, properties to differentiate strains DS- $40^{\mathrm{T}}$ and DS$45^{\mathrm{T}}$ from members of the genera Pedobacter and Sphingobacterium (Takeuchi \& Yokota, 1992; Steyn et al., 1998; Kim et al., 2006; Yoon et al., 2007). In view of the higher 16S rRNA gene sequence similarities and the absence of urease and $\alpha$-fucosidase activities, it seems reasonable to place strains DS- $40^{\mathrm{T}}$ and DS- $45^{\mathrm{T}}$ within the genus Pedobacter rather than within the genus Sphingobacterium (Steyn et al., 1998; Shivaji et al., 2005; Vanparys et al., 2005; Yoon et al., 2006, 2007; Gallego et al., 2006; Hwang et al., 2006; Ten et al., 2006). Strains DS- $40^{\mathrm{T}}$ and DS- $45^{\mathrm{T}}$ were distinguishable from recognized Pedobacter species on the basis of several phenotypic characteristics (listed in Table 1). The $16 \mathrm{~S}$ rRNA gene sequence similarity values were low enough to justify the allocation of strains DS- $40^{\mathrm{T}}$ and DS- $45^{\mathrm{T}}$ as two novel species that are distinct from the recognized Pedobacter species (Stackebrandt \& Goebel, 1994). Therefore, on the basis of the data presented, strains DS- $40^{\mathrm{T}}$ and DS- $45^{\mathrm{T}}$ represent two distinct novel species within the genus Pedobacter, for which the names Pedobacter lentus sp. nov. and Pedobacter terricola sp. nov. are proposed, respectively.

\section{Description of Pedobacter lentus sp. nov.}

Pedobacter lentus (len'tus. L. masc. adj. lentus slow, delayed, referring to the slow growth of the microorganism). 
Cells are Gram-negative, non-spore-forming, non-flagellated cocci, oval-shaped or rods $(0.4-0.8 \times 0.4-3.0 \mu \mathrm{m})$. Colonies on NA are circular, convex, smooth, glistening, pale yellow to pale orange in colour and $0.3-0.5 \mathrm{~mm}$ in diameter after incubation for 7 days at $25{ }^{\circ} \mathrm{C}$. Optimal growth occurs at $25{ }^{\circ} \mathrm{C}$; growth occurs at 4 and $31{ }^{\circ} \mathrm{C}$, but not at $32{ }^{\circ} \mathrm{C}$. Optimal $\mathrm{pH}$ for growth is 6.5-7.5; growth occurs at $\mathrm{pH} 6.0$ and 8.0, but not at $\mathrm{pH} 5.5$ or 8.5. Optimal growth occurs in the presence of $0-1.0 \%(\mathrm{w} / \mathrm{v}) \mathrm{NaCl}$; growth does not occur in the presence of more than $4 \%$ (w/v) NaCl. Growth does not occur under anaerobic conditions on NA or on NA supplemented with nitrate. Starch and Tweens 20, 40, 60 and 80 are hydrolysed, but casein, gelatin, tyrosine, hypoxanthine and xanthine are not. Ornithine decarboxylase is absent. Flexirubin-type pigments are absent. Sensitive to carbenicillin, cephalothin, lincomycin, neomycin, polymyxin B and streptomycin, but not to novobiocin or oleandomycin. The predominant menaquinone is MK-7. Major fatty acids $(>10 \%$ of total fatty acids) are iso- $\mathrm{C}_{15: 0}$ and iso- $\mathrm{C}_{17: 0} 3-\mathrm{OH}$. The DNA $\mathrm{G}+\mathrm{C}$ content is $36.0 \mathrm{~mol} \%$ (HPLC). Other phenotypic properties are shown in Table 1.

The type strain, DS $-40^{\mathrm{T}}\left(=\mathrm{KCTC} 12875^{\mathrm{T}}=\mathrm{JCM} 14593^{\mathrm{T}}\right)$, was isolated from soil from the island of Dokdo, Korea.

\section{Description of Pedobacter terricola sp. nov.}

Pedobacter terricola (ter.ri.co'la. L. masc. n. terricola a dweller of soil, referring to the isolation of the type strain from soil).

Cells are Gram-negative, non-spore-forming, non-flagellated cocci, oval-shaped or rods $(0.3-0.6 \times 0.5-5.0 \mu \mathrm{m})$; occasionally, a few cells $>10.0 \mu \mathrm{m}$ in length may occur. Colonies on NA are circular, slightly convex, smooth, glistening, pale orange in colour and $1.0-1.2 \mathrm{~mm}$ in diameter after incubation for 7 days at $25^{\circ} \mathrm{C}$. Optimal growth occurs at $25{ }^{\circ} \mathrm{C}$; growth occurs at 4 and $34{ }^{\circ} \mathrm{C}$, but not at $35{ }^{\circ} \mathrm{C}$. Optimal $\mathrm{pH}$ for growth is 6.5-7.5; growth occurs at $\mathrm{pH} 5.5$ and 8.0, but not at $\mathrm{pH} 5.0$ or 8.5. Optimal growth occurs in the presence of $0-1.0 \%(\mathrm{w} / \mathrm{v}) \mathrm{NaCl}$; growth does not occur in the presence of more than $7 \%$ $(\mathrm{w} / \mathrm{v}) \mathrm{NaCl}$. Growth does not occur under anaerobic conditions on NA or on NA supplemented with nitrate. Tweens 20, 40, 60 and 80 are hydrolysed, but casein, gelatin, starch, tyrosine, hypoxanthine and xanthine are not. Ornithine decarboxylase is absent. Flexirubin-type pigments are absent. Sensitive to carbenicillin, cephalothin, lincomycin, neomycin, streptomycin and novobiocin and slightly sensitive to polymyxin B and oleandomycin. The predominant menaquinone is MK-7. Major fatty acids ( $>10 \%$ of total fatty acids) are iso- $\mathrm{C}_{15: 0}$, iso- $\mathrm{C}_{17: 0} 3-\mathrm{OH}$ and summed feature $3\left(\mathrm{C}_{16: 1} \omega 7 c\right.$ and/or iso- $\left.\mathrm{C}_{15: 0} 2-\mathrm{OH}\right)$. The DNA G $+\mathrm{C}$ content is $36.8 \mathrm{~mol} \%$ (HPLC). Other phenotypic properties are shown in Table 1.

The type strain, DS $-45^{\mathrm{T}}\left(=\right.$ KCTC $\left.12876^{\mathrm{T}}=\mathrm{JCM} 14594^{\mathrm{T}}\right)$, was isolated from soil from the island of Dokdo, Korea.

\section{Acknowledgements}

This work was supported by the 21C Frontier Program of Microbial Genomics and Applications (grant MG05-0401-2-0) and the Support and Application Project of Biological Resources (grant M10508050004-06N0805-00410) from the Ministry of Science and Technology (MOST) of the Republic of Korea.

\section{References}

Bernardet, J.-F., Nakagawa, Y. \& Holmes, B. (2002). Proposed minimal standards for describing new taxa of the family Flavobacteriaceae and emended description of the family. Int J Syst Evol Microbiol 52, 1049-1070.

Bowman, J. P. (2000). Description of Cellulophaga algicola sp. nov., isolated from the surfaces of Antarctic algae, and reclassification of Cytophaga uliginosa (ZoBell and Upham 1944) Reichenbach 1989 as Cellulophaga uliginosa comb. nov. Int J Syst Evol Microbiol 50, 1861-1868.

Cowan, S. T. \& Steel, K. J. (1965). Manual for the Identification of Medical Bacteria. London: Cambridge University Press.

Ezaki, T., Hashimoto, Y. \& Yabuuchi, E. (1989). Fluorometric deoxyribonucleic acid-deoxyribonucleic acid hybridization in microdilution wells as an alternative to membrane filter hybridization in which radioisotopes are used to determine genetic relatedness among bacterial strains. Int J Syst Bacteriol 39, 224-229.

Gallego, V., García, M. T. \& Ventosa, A. (2006). Pedobacter aquatilis sp. nov., isolated from drinking water, and emended description of the genus Pedobacter. Int J Syst Evol Microbiol 56, 1853-1858.

Hwang, C. Y., Choi, D. H. \& Cho, B. C. (2006). Pedobacter roseus sp. nov., isolated from a hypertrophic pond, and emended description of the genus Pedobacter. Int J Syst Evol Microbiol 56, 1831-1836.

Kim, K.-H., Ten, L. N., Liu, Q.-M., Im, W.-T. \& Lee, S.-T. (2006). Sphingobacterium daejeonense sp. nov., isolated from a compost sample. Int J Syst Evol Microbiol 56, 2031-2036.

Komagata, K. \& Suzuki, K. (1987). Lipid and cell wall analysis in bacterial systematics. Methods Microbiol 19, 161-207.

Kwon, S.-W., Kim, B. Y., Lee, K.-H., Jang, K.-Y., Seok, S.-J., Kwon, J.-S., Kim, W.-G. \& Weon, H. Y. (2007). Pedobacter suwonensis sp. nov., isolated from the rhizosphere of Chinese cabbage (Brassica campestris). Int J Syst Evol Microbiol 57, 480-484.

Lanyi, B. (1987). Classical and rapid identification methods for medically important bacteria. Methods Microbiol 19, 1-67.

Margesin, R., Spröer, C., Schumann, P. \& Schinner, F. (2003). Pedobacter cryoconitis sp. nov., a facultative psychrophile from alpine glacier cryoconite. Int J Syst Evol Microbiol 53, 1291-1296.

Reichenbach, H. (1992). The order Cytophagales. In The Prokaryotes. A Handbook on the Biology of Bacteria: Ecophysiology, Isolation, Identification, Applications, 2nd edn, pp. 3631-3675. Edited by A. Balows, H. G. Trüper, M. Dworkin, W. Harder \& K. H. Schleifer. New York: Springer.

Sasser, M. (1990). Identification of bacteria by gas chromatography of cellular fatty acids. Newark, DE: MIDI Inc.

Shivaji, S., Chaturvedi, P., Reddy, G. S. N. \& Suresh, K. (2005). Pedobacter himalayensis sp. nov., from the Hamta glacier located in the Himalayan mountain ranges of India. Int J Syst Evol Microbiol 55, 1083-1088.

Stackebrandt, E. \& Goebel, B. M. (1994). Taxonomic note: a place for DNA-DNA reassociation and 16S rRNA sequence analysis in the present species definition in bacteriology. Int J Syst Bacteriol 44, 846-849. 
Steyn, P. L., Segers, P., Vancanneyt, M., Sandra, P., Kersters, K. \& Joubert, J. J. (1998). Classification of heparinolytic bacteria into a new genus, Pedobacter, comprising four species: Pedobacter heparinus comb. nov., Pedobacter piscium comb. nov., Pedobacter africanus sp. nov. and Pedobacter saltans sp. nov. Proposal of the family Sphingobacteriaceae fam. nov. Int J Syst Bacteriol 48, 165-177.

Takeuchi, M. \& Yokota, A. (1992). Proposals of Sphingobacterium faecium sp. nov., Sphingobacterium piscium sp. nov., Sphingobacterium heparinum comb. nov., Sphingobacterium thalpophilum comb. nov., and two genospecies of the genus Sphingobacterium, and synonymy of Flavobacterium yabuuchiae and Sphingobacterium spiritivorum. J Gen Appl Microbiol 38, 465-482.

Tamaoka, J. \& Komagata, K. (1984). Determination of DNA base composition by reversed-phase high-performance liquid chromatography. FEMS Microbiol Lett 25, 125-128.

Ten, L. N., Liu, Q.-M., Im, W.-T., Lee, M., Yang, D.-C. \& Lee, S.-T. (2006). Pedobacter ginsengisoli sp. nov., a novel DNase-producing bacterium isolated from soil of a ginseng field in South Korea. Int $J$ Syst Evol Microbiol 56, 2565-2570.

Vanparys, B., Heylen, K., Lebbe, L. \& De Vos, P. (2005). Pedobacter caeni sp. nov., a novel species isolated from a nitrifying inoculum. Int J Syst Evol Microbiol 55, 1315-1318.
Wayne, L. G., Brenner, D. J., Colwell, R. R., Grimont, P. A. D., Kandler, O., Krichevsky, M. I., Moore, L. H., Moore, W. E. C., Murray, R. G. E. \& other authors (1987). International Committee on Systematic Bacteriology. Report of the ad hoc committee on reconciliation of approaches to bacterial systematics. Int J Syst Bacteriol 37, 463-464.

Yoon, J.-H., Kim, H., Kim, S.-B., Kim, H.-J., Kim, W. Y., Lee, S. T., Goodfellow, M. \& Park, Y.-H. (1996). Identification of Saccharomonospora strains by the use of genomic DNA fragments and rRNA gene probes. Int J Syst Bacteriol 46, 502-505.

Yoon, J.-H., Lee, S. T. \& Park, Y.-H. (1998). Inter- and intraspecific phylogenetic analysis of the genus Nocardioides and related taxa based on 16S rRNA gene sequences. Int J Syst Bacteriol 48, 187-194.

Yoon, J.-H., Kim, I.-G., Shin, D.-Y., Kang, K. H. \& Park, Y.-H. (2003). Microbulbifer salipaludis sp. nov., a moderate halophile isolated from a Korean salt marsh. Int J Syst Evol Microbiol 53, 53-57.

Yoon, J.-H., Lee, M.-H., Kang, S.-J., Park, S.-Y. \& Oh, T.-K. (2006). Pedobacter sandarakinus sp. nov., isolated from soil. Int J Syst Evol Microbiol 56, 1273-1277.

Yoon, M.-H., Ten, L. N., Im, W.-T. \& Lee, S.-T. (2007). Pedobacter panaciterrae sp. nov., isolated from soil in South Korea. Int J Syst Evol Microbiol 57, 381-386. 